Article

\title{
Perception of Sustainability of Spanish National Parks: Public Use, Tourism and Rural Development
}

\author{
Esteban Pérez-Calderón ${ }^{1, *} \mathbb{C}$, Jorge Manuel Prieto-Ballester ${ }^{2} \mathbb{C}$, Vanessa Miguel-Barrado ${ }^{3}$ and \\ Patricia Milanés-Montero ${ }^{1}$ (D) \\ 1 Faculty of Economics, University of Extremadura, 06006 Badajoz, Spain; pmilanes@unex.es \\ 2 Faculty of Business, Finance and Tourism, University of Extremadura, 10071 Cáceres, Spain; \\ jmprieto@unex.es \\ 3 Faculty of Law, University of Extremadura, 10071 Cáceres, Spain; vmiguelb@alumnos.unex.es \\ * Correspondence: estperez@unex.es
}

Received: 21 January 2020; Accepted: 9 February 2020; Published: 12 February 2020

\begin{abstract}
In the last decade, tourism activity associated with natural areas has stood out as a driver for economic development. Thus, it is a key factor for the economic and social sustainability of the community near a protected area. This paper analyses, considering the tourist exploitation and the public use of the National Park in the last decade, the perception about the sustainability of its geographical area closest. A questionnaire was used and sent to the authorities of the villages closest to each of the 15 National Parks. The structural equation model was used for the design and analysis of the model. The results confirmed significant relationships between the perception of economic development and quality of life, but not with social development. A positive relationship between quality of life and social development is also demonstrated. The three dimensions analysed, economic, social and quality of life, are influencing the perception of sustainability of the geographical area closest to the protected natural area. The legal limitations to the public use of these natural protected areas have been considered in the assessments made by the respondents. In conclusion, National Park managers, local entrepreneurs and institutional authorities (local, regional and national) are encouraged to better coordinate the resources of the protected natural area. The dynamization of tourist activities should be encouraged while respecting the biological value of the park, as has been done so far.
\end{abstract}

Keywords: rural development; National Parks; nature tourism; public use

\section{Introduction}

The tourism business is a very important factor in economic and social development. In 2018 it contributed to $10.4 \%$ of the world's GDP, which was $3.9 \%$ higher than the previous year [1]. Spain is a tourist power and is positioned as the second-largest tourist destination in the world in terms of visitor reception [2].

Tourist activity can be particularly interesting in rural areas due to the deterioration of their main sources of wealth generation, agriculture and livestock [3,4]. The economic marginalisation of these rural areas and the ageing of their residents are causing their impoverishment and depopulation [5]. In particular, nature tourism is strongly associated with these rural areas. This type of tourism has shown constant growth in recent years, both in the world and in Spain. Thus, nature tourism can contribute to the development of rural areas that have a natural environment that is institutionally recognised for its high biological value [6].

In Spain, the figure with the greatest biological recognition and legal protection are the National Parks. This country has 15 National Parks that represent $0.76 \%$ of its territory. Likewise, this figure 
is the best known by society among all the protection categories and has a great tourist attraction, registering millions of visits annually $[7,8]$. Furthermore, Spanish National Parks represent exceptional environments with their own culture and biological personality, due to the authenticity of their resources, which is one of the country's distinguishing characteristics [9].

In accordance with the above, protected areas are considered an appropriate means of combining traditional activities with new business niches associated with rural and nature tourism, with the aim of promoting sustainable development in the area of influence of the protected natural area [10-13]. In this sense, public use of National Parks cannot be limited only to activities such as contemplation or preservation [14]. Consequently, these wonderful natural spaces must extend their potential to the social and economic sphere, and it is advisable to design sustainable development strategies [15-19].

Economic development in the areas of influence of protected natural environments should not be understood as a form of over-exploitation [19]. Achieving the self-sufficiency and sustainability of the areas bordering these natural spaces would achieve the objective set by the legal norm, since these areas of influence are usually economically disadvantaged rural areas due, among other factors, to the decline of agriculture and the limitations on the use of natural resources as a result of the declaration of a protected space $[20,21]$.

In the previous literature, you can find quite a few studies on rural development and sustainable tourism from an economic and social perspective using macroeconomic indicators. This paper contributes to the previous literature since there are very few studies referring to the perception of sustainability of this type of tourist destinations. In addition, the controversy that justifies this study would be the one that occurs when a National Park is declared and regulated by a law where an important set of limitations to its public use are related. At the same time, the main objectives include the enjoyment of the protected area and the development of its area of socioeconomic influence. These aims will be achieved through the appropriate exploitation of the attraction of the tourist destination, which is a privileged natural environment.

Thus, analysing the limited public use, recognized by law, of the National Parks and the tourist exploitation carried out in the last ten years, the study aims to answer the following question: do the residents near the National Parks perceive that their community is sustainable? According to the above, the main objective of the paper is the analysis of the perception of the economic and social development and the quality of life of the residents in the villages closest to the National Park. In addition, the relationships that are occurring between these latent factors will be measured, and also between these factors and the villagers' perception of the sustainability of their environment.

This paper is structured as follows. In Section 2, the legal framework affecting the public use of Spanish National Parks is analysed, as well as its evolution. In Section 3, the conceptual framework referring to the importance of nature tourism in the socio-economic development of a given geographical demarcation is analysed; here, too, the study hypotheses are defined. In Section 4, the sample and methodology used are detailed. In Section 5, the results of the study are drawn up.Finally, the conclusions and limitations of the paper are shown.

\section{Literature Review}

\subsection{Protected Natural Areas. Public Use of Spanish National Parks}

A protected natural area is a clearly defined geographical area recognised, dedicated and managed, through legal or other effective means, to achieve the long-term conservation of nature and associated cultural values [22].

The beginning of the international protectionist trend dates back to 1872 when Yellowstone National Park was declared in the United States [23,24]. The objective of this first declaration was based on the preservation of natural space for the enjoyment of people, due to the devastating effect of human actions on natural resources [25-27]. Focusing on the European landscape, Russia, Switzerland and Spain were the first to regulate the protection of National Parks [28,29]. 
The concepts of National Park and public use are closely linked and are in constant evolution, as can be seen in Table 1.

Table 1. Evolution of the concept of public use.

\begin{tabular}{cll}
\hline Period & \multicolumn{1}{c}{ The Function of Public Use } & \multicolumn{1}{c}{ Role of the Administration } \\
\hline Late 19th century-1930s & $\begin{array}{l}\text { Recreation and contemplative } \\
\text { enjoyment }\end{array}$ & Facilitating access \\
\hline 1930s-1960s (USA) & $\begin{array}{l}\text { Environmental education and } \\
\text { interpretation }\end{array}$ & Promote activities \\
\hline The 1970s & Recreational conditioning & $\begin{array}{l}\text { Build reception facilities (picnic areas, } \\
\text { barbecues, etc.) }\end{array}$ \\
\hline \multirow{2}{*}{ The 1980s } & $\begin{array}{l}\text { First actions in environmental } \\
\text { education and interpretation in } \\
\text { protected natural areas }\end{array}$ & $\begin{array}{l}\text { Build equipment for environmental } \\
\text { education and interpretation. } \\
\text { Public use as a tool for the management of } \\
\text { protected natural areas }\end{array}$ \\
\hline 1990s-2000 & $\begin{array}{l}\text { Social function } \\
\text { Socio-economic vision } \\
\text { Construction of visitor centres } \\
\text { Extension to tourism and leisure }\end{array}$ & $\begin{array}{l}\text { Planning in an orderly fashion } \\
\text { First studies on visitors } \\
\text { First evaluations } \\
\text { Opportunity to the private sector for } \\
\text { equipment management }\end{array}$ \\
& $\begin{array}{l}\text { A Driver of socio-economic } \\
\text { development } \\
\text { Multiple vision of public use } \\
\text { (culture, training, health...) } \\
\text { Transcendence of securities } \\
\text { Involvement of society }\end{array}$ & $\begin{array}{l}\text { Planning with network vision } \\
\text { Public use at the network level } \\
\text { Cascade planning (governance) } \\
\text { Public use as a communication strategy } \\
\text { (means of preservation) } \\
\text { Actions in favour of the quality of public } \\
\text { use (Quality Q and CETS) }\end{array}$ \\
\hline
\end{tabular}

Source: Authors [30].

Table 1 shows that the mere conservationist approach has been evolving towards a model in which the relationship of the human being with nature is promoted through the harmonization of the objectives of preservation and socioeconomic development, turning the National Parks into authentic drivers of sustainable development $[26,31]$.

In particular, in the case of Spain, the protective regime of the National Parks has undergone a significant evolution until today [28]. At the beginning, the public use of the National Parks was only related to environmental interpretation and education [20], while, at present, public use is understood as the set of activities, services and infrastructures whose aim is to bring visitors to protected natural areas closer to their natural and cultural values, from an orderly management that guarantees the conservation of these resources and the enhancement of values such as environmental education and sustainable development [32,33].

After a review of the Spanish regulations that allow the recognition of a National Park, from the first law approved in 1916 to the last one in force since 2014, we can see how two objectives are repeated, such as the biological preservation of the protected area and paying attention to the socio-economic development of the park's area of influence. Currently, the Autonomous Communities are competent in regulatory matters and the management of their own protected areas [34]. The basic regime for public use of the National Parks is the responsibility of the State and is regulated by Law 30/2014, currently in force.

\subsection{Nature Tourism: Effects on Sustainable Rural Development}

As previously argued, the tourism sector is one of the most prominent in the global economy, due to its capacity to generate income, employment and taxes $[35,36]$. This wealth-generating power can also be seen in the form of nature tourism, as it is an activity that is fully compatible with environmental preservation, allowing the promotion of traditional values and the improvement of the quality of life of the local residents [37]. All of the above can have a positive effect on the attitude of the residents of the tourist destination's area of influence, which in turn has an impact on the sustainability 
of the destination [38]. In this sense, the perceptions of local residents are shown to be a key factor in the development of sustainable tourism [39-42].

In the last decade, nature tourism has achieved great importance in international tourism [43]. Nowadays, there has been an increase in the number of tourists who are looking for tranquillity, a link with nature, the practice of sports activities or recreational value in the open air [26,30,44-46].

Tourism in National Parks can be of great socio-economic value to them and their respective areas of influence [21,47]. Among the benefits generated by nature tourism are: increased income; greater job creation; improved financing of the protected environment; or a higher level of environmental education and, consequently, a greater appreciation of the natural and cultural heritage by human beings $[44,48,49]$.

On the contrary, nature tourism can also generate important negative impacts, such as the undermining of environmental conservation, seasonal unemployment, loss of tranquillity, increased pollution, the alteration of local customs, or the increase in prices of local products and services $[26,44,50]$. In addition, the declaration of National Parks carries with it a significant limitation on the use of the occupied land demarcation and traditional activities rooted in the area that can be detrimental to local development [21,50]. In particular, current Spanish legislation limits certain activities such as hunting, fishing, certain extractions, building, among others [51].

The National Parks in Spain have become important tourist destinations. Thus, the number of visits has grown considerably since 1991, exceeding 15.44 million in 2017, as shown in Figure 1 [52]. Nature tourism, through an adequate management model, constitutes a valuable tool through which multiple benefits can be obtained $[13,19,32,53,54]$. This approach represents one of the great challenges of the current panorama, that is, the search for a balance between public use for recreational purposes, the socio-economic development of the area of influence of the National Park and the conservation of the ecosystem $[27,31,55]$.

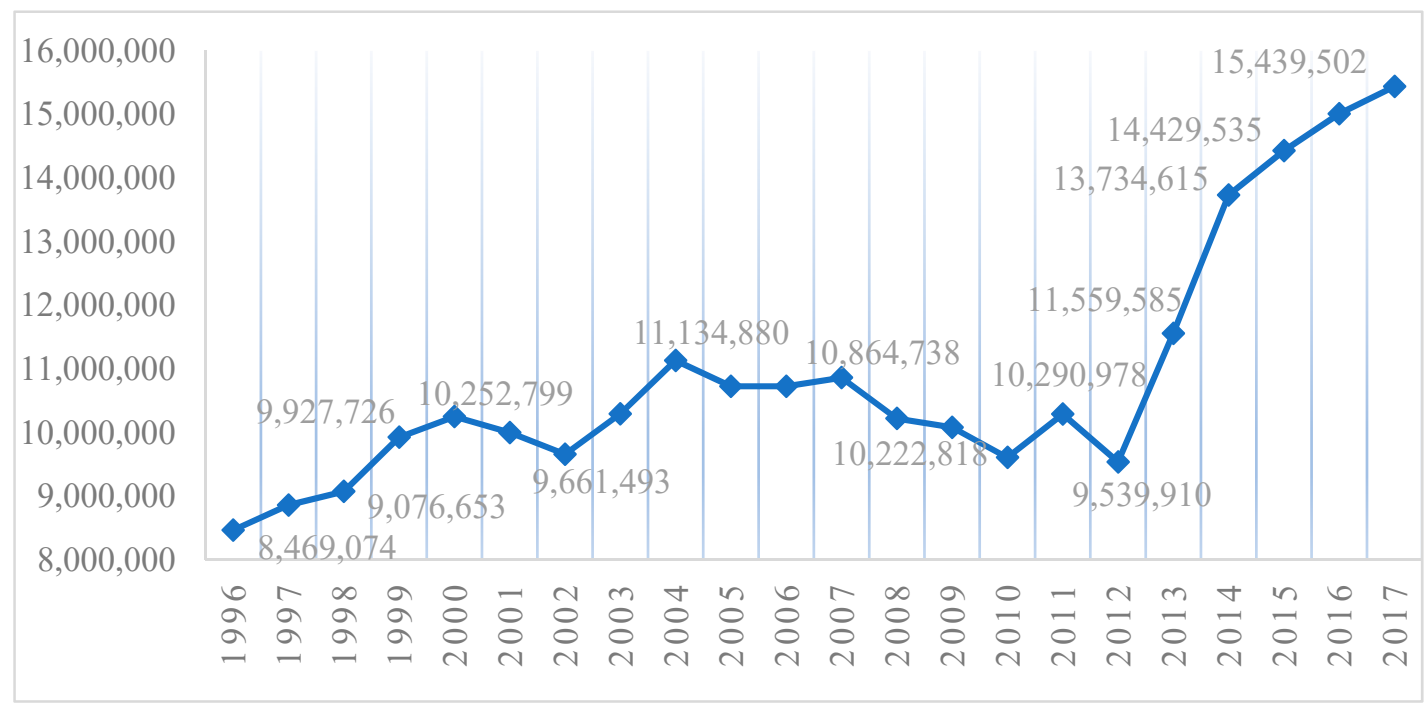

Figure 1. Evolution of visitors to National Parks in Spain [49].

In addition to the clear relationship between economic development and the sustainable development of a rural area, a number of other factors associated with the sustainability of that tourist destination can be distinguished. Thus, the perception of social development and quality of life would be factors that influence the decision to maintain residence in the village and, moreover, can have an impact on an active contribution to the maintenance of the area's resources, including those related to tourism and the biological value of the area $[11,56,57]$. According to the above, the preservation of natural and cultural heritage in villages can be reinforced by policies that involve greater community empowerment [41]. 
Considering the externalities caused by tourism in protected areas, as well as the legal limitations on public use implicit in the declaration of National Parks, it is necessary to determine the effects on the perception of environmental sustainability caused by the declaration of Spanish National Parks in their respective areas of influence. Through this study, we will be able to ratify whether the declaration of these spaces has generated a positive perception of the sustainability of the environments from a triple perspective: economic, social and quality of life. This would be an indicator of the sustainability of the area near the National Park as a tourist destination.

Several studies have demonstrated the facilitating role of economic development in social development. In particular, tourist activity can be a tool for keeping alive the customs and authenticity of a village if they are properly managed as products of interest to a tourist destination $[45,58]$.

In this way, previous studies researching the local community's perceptions of the sustainability of tourism can be consulted in the literature, taking the theory of social exchange as a starting point. According to this theory, local residents who perceive positive effects derived from tourism will agree with the development of tourism, and vice versa. Aspects such as community attachment, participation and capacity to influence society in the management of tourism, improvement of the quality of life or low negative impact in the environmental scope result in positive perceptions towards tourism and, consequently, its success and sustainability [39-42]. In this sense, tourism activities related to the traditions and culture of the destination involve greater participation by residents and are presented as an opportunity to strengthen the identity of the local community, which also translates into a positive perception of sustainable tourism development and greater support for tourism development by local residents [39].

In the previous literature, there are many references that have demonstrated the influence of economic development on the residents' quality of life [57,59]. Thus, in the study, there is a hypothesis that reflects this relationship between the perceptions of the quality of life associated with the residents' perception of economic development.

Therefore, the perception of economic development, in addition to influencing the sustainability of the environment, maybe influencing the other latent factors. Thus, the following hypotheses can be put forward, all of which refer to the perceptions of the residents of the villages closest to a National Park:

Hypothesis 1 (H1). Hypothesis 1 (H1). The perception of economic development influences the residents' perception of sustainability.

Hypothesis 2 (H2). The perception of economic development influences the residents' perception of social development.

Hypothesis 3 (H3). The perception of economic development influences the residents' perception of quality of life.

Confirmation of each of these hypotheses would confirm the effect of the three dimensions analysed on the overall satisfaction of the declaration of a National Park and, therefore, on its sustainability.

Satisfaction with the area of residence, together with the feeling of belonging and pride in the value of the biological space, maybe the motivation that facilitates the social development of the village and also on the perception of their overall satisfaction with the environment $[59,60]$.

Hypothesis 4 (H4). The residents' perception of quality of life has influence on their perception of social development.

Hypothesis 5 (H5). The residents' perception of quality of life has influences on their perception of sustainability. 
In the case of social development, there are also studies that analyse the relationships between social perceptions or attitudes, referring to traditions and customs, with the sustainable development of a tourist destination $[11,56,57]$. The last hypothesis reflects this relationship:

Hypothesis 6 (H6). The residents' perception of social development influences the on their perception of sustainability.

\section{Method}

The study sample is made up of the villages located within the National Parks' zone of socio-economic influence. The selection was based on the zoning set out in the Master Plan of the National Park Network [61]. The sample totals 169 villages. The questionnaire was sent by email to the highest representatives of the town halls (mayors) and the answers were collected through a google form. In a second round to increase the number of responses, a telephone call was made to those town halls in the towns where there was no response. In the end, 75 responses were obtained, representing $44.38 \%$ of the total initial sample. Of the fifteen National Parks, three of them did not receive any answer (Cabrera, Tablas de Daimiel and Timanfaya). The most collaborative National Park was Islas Atlánticas; to a lesser extent, Teide (See Table 2). The fieldwork was carried out in November 2019.

Table 2. Statistics of Spanish National Parks.

\begin{tabular}{ccccc}
\hline National Park & $\begin{array}{c}\text { Extension } \\
\text { Has. }\end{array}$ & Residents & $\begin{array}{c}\text { Number of } \\
\text { Villages }\end{array}$ & $\begin{array}{c}\text { \% of } \\
\text { Answer }\end{array}$ \\
\hline Aigüestortes & 14,119 & 13,564 & 10 & $50.00 \%$ \\
Cabañeros & 40,856 & 2171 & 6 & $66.67 \%$ \\
Cabrera & $90,800.52$ & 414,538 & 2 & - \\
Doñana & 54,252 & 44,296 & 4 & $75.00 \%$ \\
Garajonay & 3984 & 21,136 & 6 & $66.67 \%$ \\
Guadarrama & 33,960 & 146,603 & 34 & $52.94 \%$ \\
Islas Atlánticas & 8480 & 370,376 & 4 & $100.00 \%$ \\
Monfragüe & 18,396 & 12,520 & 14 & $50.00 \%$ \\
Ordesa & $15,696.20$ & 1843 & 6 & $66.67 \%$ \\
Picos de Europa & $67,127.59$ & 14,492 & 11 & $45.45 \%$ \\
Sierra Nevada & 85,883 & 69,014 & 44 & $29.55 \%$ \\
Tablas de Daimiel & 3030 & 30,912 & 3 & - \\
Taburiente & 4690 & 45,094 & 9 & $55.56 \%$ \\
Teide & $18,990.00$ & 275,416 & 14 & $21.43 \%$ \\
Timanfaya & 5107.50 & 22,408 & 2 & - \\
Total & $465,371.81$ & $1,484,383$ & 169 & - \\
\hline
\end{tabular}

The indicators of the socio-economic development of the villages have been those detailed below (see Table 3). Some of these variables were already used in studies such as those by Mosammam et al. [62], Woo et al. [63] and Ristić et al. [13].

IBM SPSS Statistics Version 21.0 was used to perform a descriptive analysis of the data. In addition, this software was used to check the normality of the data.

The proposed model was analysed by modelling structural equations using Partial Least Squares (PLS). This is one of the most used methodologies when the cause-effect relationships need to be analysed $[7,64,65]$ since it informs us of the sign and intensity of these relationships. A PLS path model consists in two components. Firstly, there is a structural model (the inner model) which illustrates the specified constructs and focuses on the relationships (paths) between them. Secondly, the measurement models (the outer models) show the relationships between the factors (constructs) and the indicators. While structural and measurement models are present in all types of SEMs with latent constructs, the weighting scheme represents the third specific component of the PLS approach and is used for estimating the inner weights linking latent constructs [66]. 
Table 3. Questionnaire used to collect the data ${ }^{1}$.

\begin{tabular}{l} 
Perception of Economic Development (ED) \\
\hline ED1. The level of wealth of the village, in general, has increased since the declaration of the N. Park \\
\hline ED2. The village has a greater number of services related to tourism (directly or indirectly) \\
\hline ED3. The subsidies received have led to an improvement in the environment in terms of signalling \\
\hline ED4. You think the number of tourists in your area has increased \\
\hline ED5. The municipality has increased its recreational use and has more tourist activities \\
\hline $\begin{array}{l}\text { ED6. Conflicts exist between tourism and the exploitation of activities related to agriculture and livestock, } \\
\text { mineral extraction... (primary sector) }\end{array}$
\end{tabular}

\section{Perception of Social Development (SD)}

SD1. The number of residents in the village has been maintained

SD2. Local culture and traditions have been preserved

SD3. The culture and traditions of your village are exploited as a tourist attraction

SD4. Conflicts have arisen between tourism and residents (noise, waste...)

\section{Perception of Quality of Life (QL)}

QL1. The subsidies received have led to an improvement in the area of residence in terms of infrastructure for travel to the area

QL2. An improvement in communication technologies has been noted, with greater mobile phone coverage and greater data transmission capacity

QL3. Residents would not prefer to live in another community

QL4. Since the declaration of the National Park, efficiency in resource consumption has been enhanced. For example, promoting the use of renewable energy systems to save water consumption

QL5. Residents are more environmentally friendly

QL6. You have improved the quality of life of the residents of your village

Perception of Global Satisfaction (SG)

GS1. Residents are more aware of the opportunity for the town to be in the National Park's zone of influence

GS2. The expectations generated by economic and social opportunities due to the proximity to a National Park have been fulfilled

GS3. The park has meant that the residents of this town are proud to live in this community and not in another

GS4. The park has meant that local customs and traditions are still alive

GS5. Rate your overall satisfaction with the declaration of National Park, by the economic impact it has had on your village

${ }^{1}$ The following instructions were given in the questionnaire heading: Please answer briefly or rate on a scale of 1 to 7 your perception of the impact of tourism exploitation and public use of the National Park near your village over the past 10 years.

\section{Results}

In a first descriptive analysis (see Table 4) we can see how the perception of sustainable development, depending on the effect of the declaration of the National Park near that village, obtains an average rating (3.60 out of 7). A medium-high perception of tourist activity and visitors is recognised (3.84 and 4.56). An average score is also obtained for the perception of legal limitations on public use associated with the traditional activity of these villages (3.92), in line with the low score given to the question about the increase in wealth (3.23). With respect to the social construct, the item referring to the maintenance of traditions and customs was the most valued (4.21). In the quality of life (QL), an average score was reached by declaring no preference for living elsewhere (4.27); furthermore, the 
deficient scores on ease of travel, access to ICTs or actions to respect the environment were highlighted (QL1, QL2, and QL4, respectively).

Table 4. Evaluation of the measurement model (starting elements).

\begin{tabular}{|c|c|c|c|c|c|}
\hline $\begin{array}{l}\text { Latent Variables and } \\
\text { Their Indicators }\end{array}$ & Mean & S. Desv. & Loading & $\begin{array}{l}\text { Composite } \\
\text { Reliability }\end{array}$ & AVE \\
\hline $\begin{array}{c}\text { Perception of } \\
\text { Economic } \\
\text { Development (ED) }\end{array}$ & - & - & - & 0.8540 & 0.5391 \\
\hline ED1 & 3.23 & 1.5902 & 0.8460 & - & - \\
\hline ED2 & 3.84 & 1.7323 & 0.8467 & - & - \\
\hline ED3 & 3.89 & 1.5987 & 0.5274 & - & - \\
\hline ED4 & 4.56 & 1.7876 & 0.8611 & - & - \\
\hline ED5 & 3.77 & 1.6404 & 0.8825 & - & - \\
\hline ED6 & 3.92 & 1.9225 & 0.0575 & - & - \\
\hline $\begin{array}{l}\text { Perception of Social } \\
\text { Development (SD) }\end{array}$ & - & - & - & 0.7924 & 0.5036 \\
\hline SD1 & 3.75 & 1.8678 & 0.8804 & - & - \\
\hline SD2 & 4.81 & 1.6165 & 0.7044 & - & - \\
\hline SD3 & 4.27 & 1.7578 & 0.7587 & - & - \\
\hline SD4 & 3.16 & 1.6687 & 0.4092 & - & - \\
\hline $\begin{array}{l}\text { Perception of Quality } \\
\text { of Life (QL) }\end{array}$ & - & - & - & 0.8409 & 0.5084 \\
\hline QL1 & 2.94 & 1.6406 & 0.6956 & - & - \\
\hline QL2 & 2.63 & 1.4024 & 0.8007 & - & - \\
\hline QL3 & 4.27 & 2.0110 & 0.0501 & - & - \\
\hline QL4 & 2.97 & 1.559 & 0.7969 & - & - \\
\hline QL5 & 4.05 & 1.692 & 0.7875 & - & - \\
\hline QL6 & 3.17 & 1.6795 & 0.8171 & - & - \\
\hline $\begin{array}{l}\text { Global Satisfaction } \\
\text { Perception (GS) }\end{array}$ & - & - & - & 0.9323 & 0.7339 \\
\hline GS1 & 3.36 & 1.5124 & 0.8209 & - & - \\
\hline GS2 & 2.72 & 1.4384 & 0.8913 & - & - \\
\hline GS3 & 3.57 & 1.8756 & 0.8905 & - & - \\
\hline GS4 & 2.64 & 1.6655 & 0.8347 & - & - \\
\hline GS5 & 3.60 & 1.6925 & 0.8436 & - & - \\
\hline
\end{tabular}

A test of normality was then done. The results showed that all variables have a normal distribution. Reliability was evaluated by considering a standardized external load greater or slightly less than 0.70 (see Table 4). The elimination of these indicators resulted in an increase in composite reliability or Mean-Variance Extracted (AVE), as suggested by Hair et al. [67].

The model reliability indicators are shown below, once the elements that do not exceed the reliability cut have been eliminated. The AVE values (defined as the great average of the square of the indicators associated with the constructions), exceed 0.60 , thus demonstrating the convergent validity for all cases. The composite reliability of the 4 constructs is also satisfactory as the values ranged from 0.85 to 0.93 (see Table 5).

Table 5. Evaluation of the measurement model (final elements).

\begin{tabular}{ccccc}
\hline & AVE & $\begin{array}{c}\text { Composite } \\
\text { Reliability }\end{array}$ & R Square & Cronbach's Alpha \\
\hline ED & 0.7586 & 0.9263 & - & 0.8936 \\
SD & 0.6643 & 0.8551 & 0.2134 & 0.7553 \\
QL & 0.6092 & 0.8559 & 0.5232 & 0.8396 \\
GS & 0.7340 & 0.9323 & 0.8348 & 0.9090 \\
\hline
\end{tabular}


Discriminant validity assessed using the criteria defined by Fornell and Larcker [68], which compares the square root of the AVE values with the correlation of the latent variable, was also satisfactory. In fact, as shown in Table 6, the square root of the AVE of each construct is greater than its correlation with any other construct.

Table 6. Matrix of correlation between latent variables.

\begin{tabular}{ccccc}
\hline & QL & ED & SD & GS \\
\hline QL & 0.7805 & & & \\
ED & 0.7233 & 0.8710 & & \\
SD & 0.4611 & 0.3526 & 0.8151 & \\
GS & 0.8460 & 0.8288 & 0.5254 & 0.8567 \\
\hline
\end{tabular}

To evaluate the structural model, the R-square for each dependent construct was analysed, as well as the meaning of the trajectories, using Bootstrapping [67]. Figure 2 shows the results of the estimation of the trajectory coefficients describing the relationships between the different perceptions of the respondents. The standard errors were bootstrapped by considering 2,500 sub-samples, created with observations randomly drawn from the original set of data (with replacement).

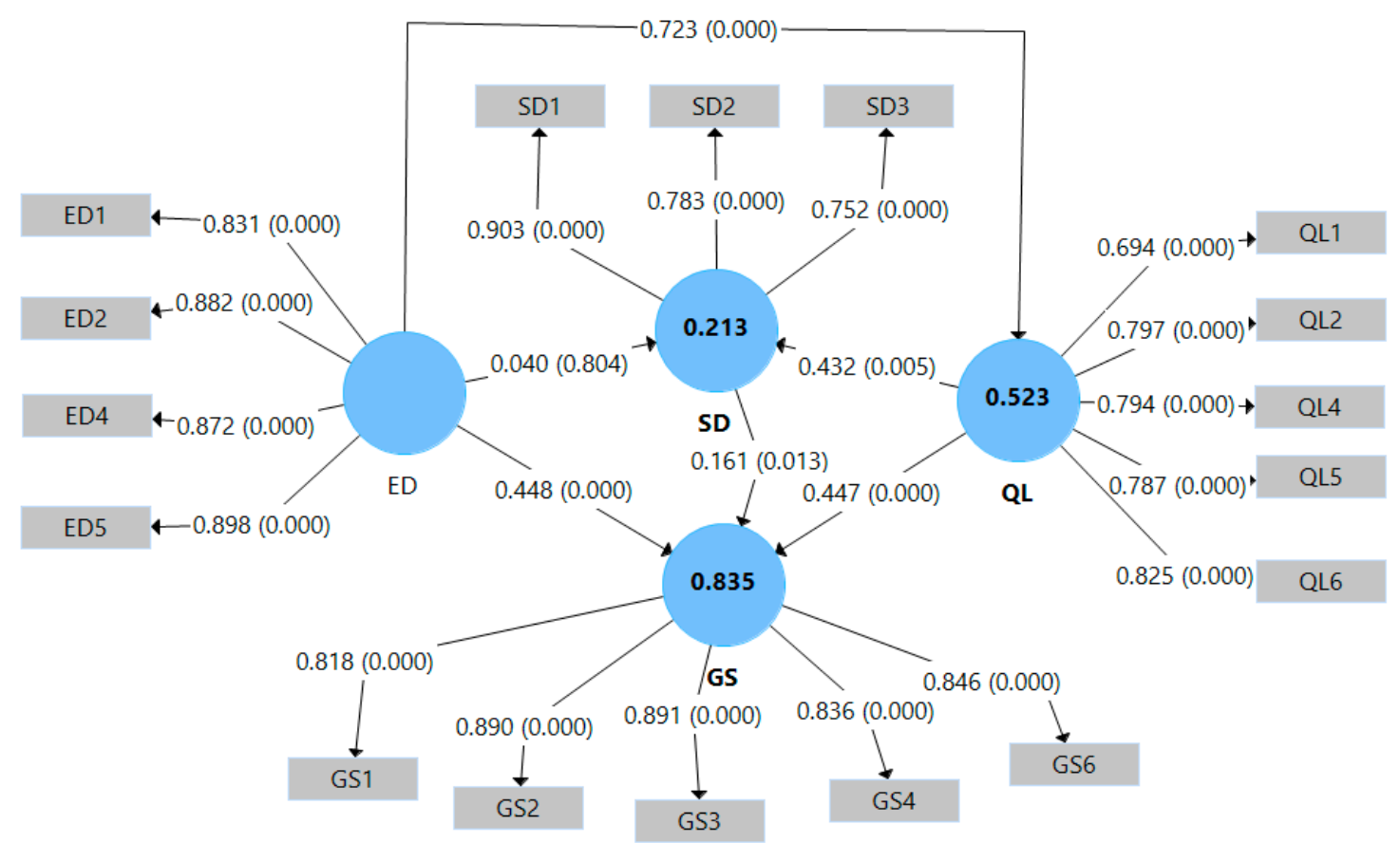

Figure 2. Estimation of the structural equation model. Notes: ED, Economic Development; SD, Social Development; QL, Quality of Life; GS, Global Satisfaction.

According to the results shown in Table 7, the latent endogenous variables of the model have a weak to moderate explanatory power. The model can explain $21.3 \%$ of the residents' perceptions of social development, $51.3 \%$ of those related to the quality of life and $83.5 \%$ of those associated with the sustainability of the village in terms of public use of the National Park (see Figure 2).

The results of the direct structural relations reveal that all the hypothetical relations are statistically significant, except the one referred to in Hypothesis 2. Four hypotheses are significant at a level of $1 \%$ (value $p<0.01$ ), hypothesis 6 is significant at $5 \%$ (value $p<0.05$ ). Social development (SD) is influenced by the quality of life (QL) but not by economic development (ED). On the other hand, QL is strongly influenced by ED (0.723). The results also show the positive and significant effects of ED and 
QL constructs, with very similar importance ( 0.448 and 0.447 , respectively), and to a lesser extent of SD (0.161).

Table 7. Tests of hypotheses for direct effects between latent variables.

\begin{tabular}{lcccc}
\hline & Original Sample & Standard Dev. & T-Statistic & $\boldsymbol{p}$ Values \\
\hline $\mathrm{H} 1 . \mathrm{ED} \rightarrow \mathrm{GS}$ & 0.4484 & 0.0670 & 6.6884 & 0.0000 \\
$\mathrm{H}$ 2. ED $\rightarrow$ SD & 0.0400 & 0.1671 & 0.2415 & 0.8108 \\
$\mathrm{H} 3 . \mathrm{ED} \rightarrow \mathrm{QL}$ & 0.7233 & 0.0472 & 15.3085 & 0.0000 \\
$\mathrm{H} 4 . \mathrm{QL} \rightarrow \mathrm{SD}$ & 0.4322 & 0.1586 & 2.7796 & 0.0055 \\
$\mathrm{H}$ 5. QL $\rightarrow$ GS & 0.4475 & 0.0817 & 5.4785 & 0.0000 \\
$\mathrm{H} 6 . \mathrm{SD} \rightarrow \mathrm{GS}$ & 0.1609 & 0.0627 & 2.5686 & 0.0114 \\
\hline
\end{tabular}

\section{Conclusions}

The study analyses the effects of public use of National Parks in Spain on the perception of sustainability in their immediate geographical area. The evaluations of indicators associated with three dimensions of community sustainability are compiled: economic and social development and the quality of life of its people. The assessments are carried out by some of the main stakeholders such as the mayors of the villages. One advantage of choosing this type of participant is that we have the opinion of a person with quality information on the reality of each village. The villages selected are those included in what is known as the park's zone of influence, legally defined according to the criteria of geographical proximity to the protected natural area [61]. Both the choice of the respondents and the choice of the villages contribute to what has been done in the previous literature.

According to the results of the analysis, the perception of economic development conditions the perception of the quality of life, not being the same for the case of social development. Likewise, quality of life is influencing the perception of social development. The three dimensions analysed are affecting the community's perception of sustainability, with the social development dimension doing so to a lesser extent. The other two factors have a very similar average impact.

Once the results have been analysed, the park managers are encouraged to improve coordination between the resources of the protected natural environment and its area of influence. That is, greater collaboration between National Park managers, local companies, village authorities and public administrations. This, applied to current funding resources or their possible extension, would lead to the recommendation of the development of new activities and initiatives aimed at making these destinations more dynamic for tourism. Villagers and local businesses should be more involved in such initiatives. In this way, in addition to boosting their economy, it will be possible to develop an attitude and a feeling of pride in the intangible property of the natural resource that will have an impact on the sustainability of the resource and the environment itself.

In accordance with Eagles et al. [44], and Job et al. [54], the goals of sustainable tourism in protected areas include, in addition to offering the contemplation of the natural and cultural heritage of that environment through efficient long-term management, the implementation of management practices that minimize the negative impacts of the public use that is made and the maximization of the positive effects at the social, cultural, ecological and economic levels. The above will be done taking into account the evaluation of the indicators of each dimension analysed in this study and other previous ones $[38,69]$.

Some advisable actions aimed at increasing the assessment of the perception of the sustainability of the National Park would be the following:

- To monitor the subsidies received by the localities in order to ensure the return of this investment and to redirect them if necessary in the future.

- A greater dynamization of the tourist activities associated with the traditions and customs of the localities. Here a benchmarking activity and the success stories in protected natural environments can be good references to propose new initiatives or improve the current ones. 
- To carry out investments or redirect funds to improve the villagers' quality of life in terms of access to information and communication technologies, movement within the area and with other nearby villages/towns/cities, improvement of signposting of infrastructures, monuments or natural points of special interest in the area.

In accordance with this study, it is essential to stress the need for a sustainable tourism management model in Spanish National Parks that combines the perspective of environmental conservation with that of economic and social development and the quality of life of their closest villagers. The management model that would be most beneficial for the sustainability of National Parks and protected natural areas, in general, would be one that, from the conservation of natural resources, promotes public use of these areas in order to positively influence the economic growth of their closest area of influence.

Therefore, a more dynamic use of the public area near the park will cause an improvement in the economic indicators and this will be perceived as such by the residents of these areas. Once this improvement in the economic situation occurs, the direct and indirect effects on overall satisfaction with the protected area will increase. In addition, better use of public resources that provide infrastructure and communications will increase the quality of life of residents and directly and indirectly increase their satisfaction. This satisfaction will be key to the sustainability of the protected environment.

The results obtained in this paper for the National Parks can serve as an example for the rest of the areas and figures of protected spaces. Parks are the natural spaces with the greatest limitation in terms of public use. Thus, if sustainable management of the space is achieved, it will be the best proof that the sustainability of this type of environment can be achieved by generating sustainable development for its areas of influence while safeguarding its biological value.

Finally, the results of this study invite us to improve the work carried out and to continue investigating this interesting subject. It is true that it was decided to send a questionnaire with a few questions in order to get a high number of answers. Thus, the paper could be improved by increasing the number of items, that is, the detail of the components of each factor. In addition, in order to increase the number of responses, it might have been preferable to conduct a personal interview rather than using the telephone and the web form.

As future lines of work, it is proposed to carry out a characterisation of the managers, entrepreneurs and local authorities in those National Parks or other protected natural environments that are proving to be a successful tourist destination. This will help to focus on funds and efforts on the development of these characteristics in the National Parks and their nearest villages.

In addition, the perception of sustainability of other very important stakeholders for the sustainable development of these communities taking into account the public use that has been given in recent years and the potential that still presents for the future. Thus, the local business mass or the villagers themselves should be taken into account in future work.

Author Contributions: Conceptualization, J.M.P.-B. and V.M.-B.; methodology, E.P.-C. and P.M.-M.; software, E.P.-C.; validation, P.M.-M.; data collection and treatment, V.M.-B.; preparation of the original draft of the manuscript, J.M.P.-B. and V.M.-B.; review and editing of the manuscript, E.P.-C. and P.M.-M.; supervision, E.P.-C. All authors have read and agreed to the published version of the manuscript.

Funding: This research was funded by European Regional Development Fund, European Union “A way of making Europe", and by Council of Economy and Infrastructure, Regional Government of Extremadura (Spain), grant number GR18128.

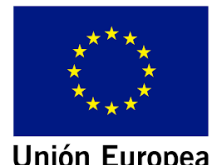

Una manera de hacer Europa

Unión Europea

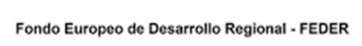

JUNTA DE EXTREMADURA

Consejería de Economía e Infraestructuras

Conflicts of Interest: The authors declare no conflict of interest. 


\section{References}

1. World Travel \& Tourism Council. Travel \& Tourism Economic Impact 2019 World; WTTC: London, UK, 2019.

2. Organización Mundial de Turismo. Turismo, Comercio y La OMT [Comunicado de Prensa]; OMT: Madrid, Spain, 2018.

3. MacDonald, R.; Jolliffe, L. Cultural Rural Tourism: Evidence from Canada. Ann. Tour. Res. 2003, 30, 307-322. [CrossRef]

4. Jaafar, M.; Rasoolimanesh, S.M.; Lonik, K.A.T. Tourism Growth and Entrepreneurship: Empirical Analysis of Development of Rural Highlands. Tour. Manag. Perspect. 2015, 14, 17-24. [CrossRef]

5. Li, Y.; Westlund, H.; Liu, Y. Why Some Rural Areas Decline While Some Others Not: An Overview of Rural Evolution in the World. J. Rural Stud. 2019, 68, 135-143. [CrossRef]

6. Hall, D. Rural Tourism Development in Southeastern Europe: Transition and the Search for Sustainability. Int. J. Tour. Res. 2004, 6, 165-176. [CrossRef]

7. Cordente-Rodríguez, M.; Mondejar-Jimenez, J.A.; Villanueva-Alvaro, J.J. Sustainability of Nature: The Power of the Type of Visitors. E Environ. Mag. 2014, 13, 2437-2447. [CrossRef]

8. EUROPARC-España. Anuario 2018 Del Estado de Las Áreas Protegidas En España; EUROPARC-España: Madrid, Spain, 2019.

9. Rada, B. Parques Nacionales: Razones Para Una Ley. Ambienta 2014, 106, 4-15.

10. Thomas, L.; Middleton, J. Guidelines for Management Planning of Protected Areas; IUCN: Gland, Switzerland, 2003. [CrossRef]

11. Kim, K.; Uysal, M.; Sirgy, M.J. How Does Tourism in a Community Impact the Quality of Life of Community Residents? Tour. Manag. 2013, 36, 527-540. [CrossRef]

12. Weaver, D.B.; Lawton, L.J. A New Visitation Paradigm for Protected Areas. Tour. Manag. 2017, 60, $140-146$. [CrossRef]

13. Ristić, D.; Vukoičić, D.; Milinčić, M. Tourism and Sustainable Development of Rural Settlements in Protected Areas-Example NP Kopaonik (Serbia). Land Use Policy 2019, 89. [CrossRef]

14. Rodary, E.; Aubertin, C. Protected Areas, Sustainable Land? Ashgate Publishing: Milano, Pennsylvania, 2012.

15. Font, X.; Garay, L.; Jones, S. Sustainability Motivations and Practices in Small Tourism Enterprises in European Protected Areas. J. Clean. Prod. 2016, 137, 1439-1448. [CrossRef]

16. Naughton-Treves, L.; Holland, M.B.; Brandon, K. The Role of Protected Areas in Conserving Biodiversity and Sustaining Local Livelihoods. Annu. Rev. Environ. Resour. 2005, 30, 219-252. [CrossRef]

17. West, P.; Igoe, J.; Brockington, D. Parks and Peoples: The Social Impact of Protected Areas. Annu. Rev. Anthropol. 2006, 35, 251-277. [CrossRef]

18. Mose, I. Protected Areas and Regional Development in Europe; Shgate Publishing: Aldershot, UK, 2007.

19. Saviano, M.; Di Nauta, P.; Montella, M.M.; Sciarelli, F. Managing Protected Areas as Cultural Landscapes: The Case of the Alta Murgia National Park in Italy. Land Use Policy 2018, 76, 290-299. [CrossRef]

20. Hidalgo, S. Uso Público En Parques Naturales. Análisis Comparado de Andalucía y de Castilla y León (Tesis Doctoral); Universidad de Granada: Granada, Spain, 2006.

21. Ghoddousi, S.; Pintassilgo, P.; Mendes, J.; Ghoddousi, A.; Sequeira, B. Tourism and Nature Conservation: A Case Study in Golestan National Park, Iran. Tour. Manag. Perspect. 2018, 26, 20-27. [CrossRef]

22. Dudley, N. Guidelines for Applying Protected Area Management Categories; UICN: Gland, Switzerland, 2008.

23. Smith, L. The Evolving National Park Idea: Yellowstone National Park, 1872-1890 (Doctoral Dissertation); College of Letters \& Science-Bozeman: Bozeman, Montana, 1999.

24. Foresta, R.A. America's National Parks and Their Keeper; Resources for the Future: Washington, DC, USA, 2011.

25. Nash, J. Wilderness and the American Mind; Yale: New Haven, CT, USA, 1997.

26. Bell, J.; Stockdale, A. Evolving National Park Models: The Emergence of an Economic Imperative and Its Effect on the Contested Nature of the "national" Park Concept in Northern Ireland. Land Use Policy 2015, 49, 213-226. [CrossRef]

27. Austin, R.; Thompson, N.; Garrod, G. Understanding the Factors Underlying Partnership Working: A Case Study of Northumberland National Park, England. Land Use Policy 2016, 50, 115-124. [CrossRef]

28. Iniesta, P. Parques Nacionales: Crónica Bibliográfica de Su Régimen Jurídico. Obs. Medioambient. 2001, 4, 407-414.

29. Watson, J.E.M.; Dudley, N.; Segan, D.B.; Hockings, M. The Performance and Potential of Protected Areas. Nature 2014, 515, 67-73. [CrossRef] 
30. Gómez-Limón, J.; García, D. Capacidad de Acogida de Uso Público En Los Espacios Naturales Protegidos; Organismo Autónomo Parques Nacionales (OAPN): Madrid, Spain, 2014.

31. DeFries, R.; Hansen, A.; Turner, B.L.; Reid, R.; Liu, J. Land Use Change around Protected Areas: Management to Balance Human Needs and Ecological Function. Ecol. Appl. 2007, 17, 1031-1038. [CrossRef]

32. Pulido, J.I. Criterios Para Una Política Sostenible En Los Parques Naturales de Andalucía. Ph.D. Thesis, Universidad de Jaén, Jaén, Spain, 2005. [CrossRef]

33. Das, M.; Chatterjee, B. Ecotourism: A Panacea or a Predicament? Tour. Manag. Perspect. 2015, 14, 3-16. [CrossRef]

34. Vozmediano, J. Incidencia de La Doctrina Del Tibunal Constitucional En La Gestión de Los Parques Nacionales. Rev. Jurídica Castilla Y León 2005, 7, 13-62.

35. Choi, H.S.C.; Sirakaya, E. Sustainability Indicators for Managing Community Tourism. Tour. Manag. 2006, 27, 1274-1289. [CrossRef]

36. Dwyer, L.; Forsyth, P. Economic Measures of Tourism Yield: What Markets to Target? Int. J. Tour. Res. 2008, 10, 155-168. [CrossRef]

37. Baum, J.; Cumming, G.S.; De Vos, A. Understanding Spatial Variation in the Drivers of Nature-Based Tourism and Their Influence on the Sustainability of Private Land Conservation. Ecol. Econ. 2017, 140, 225-234. [CrossRef]

38. Jurowski, C.; Uysal, M.; Williams, D.R. A Theoretical Analysis of Host Community Resident Reactions to Tourism. J. Travel Res. 1997, 36, 3-11. [CrossRef]

39. Olya, H.G.T.; Gavilyan, Y. Configurational Models to Predict Residents' Support for Tourism Development. J. Travel. Res. 2016, 56, 893-912. [CrossRef]

40. Alipour, H.; Olya, H.; Forouzan, I. Environmental Impacts of Mass Religious Tourism: From Residents' Perspectives. Tour. Anal. 2017, 22, 167-183. [CrossRef]

41. Olya, H.G.T.; Alipour, H.; Gavilyan, Y. Different Voices from Community Groups to Support Sustainable Tourism Development at Iranian World Heritage Sites: Evidence from Bisotun. J. Sustain. Tour. 2018, 26, 1728-1748. [CrossRef]

42. Olya, H.G.T.; Shahmirzdi, E.K.; Alipour, H. Pro-Tourism and Anti-Tourism Community Groups at a World Heritage Site in Turkey. Curr. Issues Tour. 2017, 22, 763-785. [CrossRef]

43. Balmford, A.; Beresford, J.; Green, J.; Naidoo, R.; Walpole, M.; Manica, A. A Global Perspective on Trends in Nature-Based Tourism. PLoS Biol. 2009, 7, e1000144. [CrossRef]

44. Eagles, P.F.J.; Mccool, S.F.; Haynes, C.D. Sustainable Tourism in Protected Areas: Guidelines for Planning and Management; IUCN, Ed.; UICN: Gland, Switzerland, 2002. [CrossRef]

45. Ramkissoon, H.; Weiler, B.; Smith, L.D.G. Place Attachment and Pro-Environmental Behaviour in National Parks: The Development of a Conceptual Framework. J. Sustain. Tour. 2012, 20, 257-276. [CrossRef]

46. Reinius, S.W.; Fredman, P. Protected Areas as Attractions. Ann. Tour. Res. 2007, 34, 839-854. [CrossRef]

47. Benayas, J.; Muñoz, M. Nuevos Retos y Oportunidades Para La Financiación de Los Servicios de Uso Público En Los Espacios Naturales Protegidos. Ecosistemas 2007, 16, 125-136. [CrossRef]

48. Baral, N.; Stern, M.J.; Bhattarai, R. Contingent Valuation of Ecotourism in Annapurna Conservation Area, Nepal: Implications for Sustainable Park Finance and Local Development. Ecol. Econ. 2008, 15, 218-227. [CrossRef]

49. Ryan, C.; Gu, H.; Zhang, W. The Context of Chinese Tourism-An Overview and Implications for Research. In Tourism in China: Destination, Cultures and Communities; Ryan, C., Gu, W., Eds.; Routledge: Nueva York, NY, USA, 2009; pp. 327-336.

50. Park, D.B.; Lee, K.W.; Choi, H.S.; Yoon, Y. Factors Influencing Social Capital in Rural Tourism Communities in South Korea. Tour. Manag. 2012, 33, 1511-1520. [CrossRef]

51. Ley 30/2014, de 3 de Diciembre, de Parques Nacionales. Available online: https://www.boe.es/buscar/pdf/ 2014/BOE-A-2014-12588-consolidado.pdf (accessed on 17 January 2020).

52. Ministerio Para la Transición Económica MITECO. Datos de Visitantes a los Parques Nacionales (1996-2017). Available online: https://www.miteco.gob.es/es/red-parques-nacionales/la-red/gestion/visitasppnn_tcm3067283.pdf (accessed on 11 January 2020).

53. Aparicio, M. El Reto Del Turismo En Los Espacios Naturales Protegidos Españoles: La Integración Entre Conservación, Calidad y Satisfacción (Tesis Doctoral), 2012. Open Academic Production of the UCM. Available online: https://eprints.ucm.es/20836/ (accessed on 11 February 2020). 
54. Job, H.; Becken, S.; Lane, B. Protected Areas in a Neoliberal World and the Role of Tourism in Supporting Conservation and Sustainable Development: An Assessment of Strategic Planning, Zoning, Impact Monitoring, and Tourism Management at Natural World Heritage Sites. J. Sustain. Tour. 2017, 25, 1697-1718. [CrossRef]

55. Frost, W.; Hall, C. Tourism and National Parks: International Perspectives on Development, Histories and Change; Routledge: Oxon, MD, USA, 2009.

56. Lee, T.H. Influence Analysis of Community Resident Support for Sustainable Tourism Development. Tour. Manag. 2013, 34, 37-46. [CrossRef]

57. Jeon, M.M.; Kang, M.(Michelle); Desmarais, E. Residents' Perceived Quality Of Life in a Cultural-Heritage Tourism Destination. Appl. Res. Qual. Life 2016, 11, 105-123. [CrossRef]

58. Nunkoo, R.; Gursoy, D. Residents' Support for Tourism. An Identity Perspective. Ann. Tour. Res. 2012, 39, 243-268. [CrossRef]

59. Nunkoo, R.; So, K.K.F. Residents' Support for Tourism. J. Travel Res. 2015, 55, 847-861. [CrossRef]

60. Liang, Z.X.; Hui, T.K. Residents' Quality of Life and Attitudes toward Tourism Development in China. Tour. Manag. 2016, 57, 56-67. [CrossRef]

61. Real Decreto 389/2016, de 22 de Octubre, por el que se Aprueba el Plan Director de la Red de Parques Nacionales. Available online: https:/www.boe.es/diario_boe/txt.php?id=BOE-A-2016-9690 (accessed on 17 January 2020).

62. Mosammam, H.M.; Sarrafi, M.; Nia, J.T.; Heidari, S. Typology of the Ecotourism Development Approach and an Evaluation from the Sustainability View: The Case of Mazandaran Province, Iran. Tour. Manag. Perspect. 2016, 18, 168-178. [CrossRef]

63. Woo, E.; Kim, H.; Uysal, M. Life Satisfaction and Support for Tourism Development. Ann. Tour. Res. 2015, 50, 84-97. [CrossRef]

64. Mondéjar-Jiménez, J.; Mondéjar-Jiménez, J.A.; Vargas-Vargas, M.; Gázquez-Abad, J. Personal Attitudes in Environmental Protection. Int. J. Environ. Res. 2012, 6, 1039-1044.

65. Fritzsche, D.; Oz, E. Personal values' influence on the ethical dimension of decision making. J. Bus. Ethics 2007, 75, 335-343. [CrossRef]

66. Monecke, A.; Leisch, F. SemPLS: Structural equation modeling using partial least squares. J. Stat. Softw. 2012, 48, 1-32. [CrossRef]

67. Hair, J.F.; Ringle, C.M.; Sarstedt, M. PLS-SEM: Indeed a Silver Bullet. J. Mark. Theory Pract. 2011, 19, $139-151$. [CrossRef]

68. Fornell, C.; Larcker, D.F. Evaluating Structural Equation Models with Unobservable Variables and Measurement Error. J. Mark. Res. 1981, 18, 39. [CrossRef]

69. Campón-Cerro, A.M.; Folgado-Fernández, J.A.; Hernández-Mogollón, J.M. Rural Destination Development Based on Olive Oil Tourism: The Impact of Residents' Community Attachment and Quality of Life on Their Support for Tourism Development. Sustainability 2017, 9, 1624. [CrossRef]

(C) 2020 by the authors. Licensee MDPI, Basel, Switzerland. This article is an open access article distributed under the terms and conditions of the Creative Commons Attribution (CC BY) license (http://creativecommons.org/licenses/by/4.0/). 